\title{
In-Plane Behavior of Tuff Masonry Panels Strengthened with Fibre-Reinforced Plastic Cross Layout
}

\author{
G. Marcari $^{1}$, D.V. Oliveira ${ }^{1}$, G. Fabbrocino ${ }^{2}$ and P.B. Lourenço ${ }^{1}$ \\ ${ }^{1}$ Department of Civil Engineering \\ ISISE, University of Minho, Portugal \\ ${ }^{2}$ Strega Lab, University of Molise, Italy
}

\begin{abstract}
The paper is aimed at understanding the in-plane shear-compression behaviour of tuff masonry panels strengthened with FRP cross layout. Based on a previous experimental work carried out by some of the authors, a quantitative analysis of the contributions of FRP and bare masonry to reinforced panel shear capacity has been carried out. Force-displacement relationships of all the tested panels are provided, including the intermediate debonding strains. Finally, a critical comparison between the experimental masonry shear strength and the ones calculated according to analytical models suggested by the Italian code NTC 08 and the CNR-DT 200/2004 guideline is presented.
\end{abstract}

Keywords: tuff masonry, FRP, cross layout, shear strength, CNR-DT 200/2004.

\section{Introduction}

Studies at various levels on the use of FRP as strengthening materials have been numerous. However, only few of them concern the case on FRP-strengthened masonry built with soft stones (i.e. tuff, calcarenite, etc.), which constitute the majority of historic centres and architectural heritage in the Mediterranean area, particularly southern Italy [1-2].

Marcari et al. [3] tested full scale yellow tuff masonry panels under shearcompression, to investigate the feasibility of using CFR and GFRP sheets as strengthening material. The objective of this study was to determine failure modes, mechanisms, strength and displacement capacity using a cross and grid FRP configurations to optimize material placement.

Strengthening techniques such as two-dimensional CFRP and GFRP fabrics were investigated respectively by Faella et al. [4] and Prota et al. [5], thorough diagonal 
compression tests. In [6-7] investigation on strengthening methods for tuff building models with GFRP sheets and grids was carried out through shaking table tests.

Moreover, strain profiles and the corresponding stresses developed in the FRP systems have been generally not reported, and available studies on shear bond tests between FRP and tuff stones were performed according to non-standardised tests [8]. The prediction of the strength of FRP-strengthened masonry walls subject to inplane forces plays a crucial role in the seismic design and assessment of historic masonry buildings reinforced with composite materials.

In compliance with modern design codes [9-10], the guidelines ACI 2008 [11] and CNT 200/2004 [12] adopt an additive approach to calculate the total shear load carried by the strengthened specimens, where the contribution of the horizontal reinforcement is added to the shear strength of unreinforced masonry.

As for the masonry contribution, experimental investigations have shown that different failure modes can be achieved, namely diagonal shear or shear/flexure depending on the type of masonry construction and the FRP strengthening layout [13-14].

The guidelines ACI 2008 [11] and CNR 200/2004 [12] provide design equations for FRP plies applied in grid configuration. Analytical models for FRP sheets orthogonal to the bed joints can be found in Roca et al. [15] and Benedetti and Steli [16], whilst for grid layout in Triantafillou [17].

Closed-form expressions for cross layout have been mostly derived by strut-andtie models [18-19]. For $\Lambda$-strengthening layout, references can be found in Zhao et al. [20], while for two-dimensional fabrics or finer grids applied over the whole surface, analytical methods been developed by Faella et al. [21] and Stratford et al. [22]. However, the lack of research in the field of historic masonry involve the body of these design rules in CNR DT or ACI 2008 is mostly adapted from those obtained on concrete structures.

With reference to tuff masonry, some outstanding issues that needed to be further investigated are: (i) the bond behaviour between and FRP and tuff masonry substrate, (ii) the effects of long-term environmental exposure on bond behaviour of FRP-masonry applications and (iii) the capability of analytical methods to accurately predict the in-plane shear capacity of masonry strengthened with FRP cross layout.

The aim of the paper is to progress in knowledge about strengthened tuff masonry panels with FRP cross layout, subjected to shear-compression loading. Within the research carried out by Marcari et al. [3], new experimental force-displacement relationships are presented for panels strengthened with CFRP and GFRP, both with low and high density. Analysis of strain measurement allowed to quantify the contribution of FRP to the shear strength of the panels.

The contribution of the unreinforced masonry has been also investigated. Results have been used to assess reliability of strength formulae provided by recent Italian code provisions and guidelines (NCT 08 and CNR DT 200/2004). 


\section{The experimental database}

\subsection{Unstrengthened panels}

\subsubsection{Test programme}

Marcari et al. [3] investigated the behaviour of full scale multiple-leaf tuff masonry panels having dimensions of $1570 \times 1480 \times 530 \mathrm{~mm}$ and subjected to monotonic inplane shear-compression loading (Figure 1). The panels were characterized by good transversal connection. Yellow tuff stones with compressive strength of $2.1 \mathrm{MPa}$ and mortar with compressive strength of 2.0 MPa were used.

Two panels were tested under vertical compression, and results in terms of curvediplacement relationships can be found in Marcari et al. [23]. The mean compressive strength calculated over the gross section approached the value $1.1 \mathrm{MPa}$. The average elastic modulus was $635 \mathrm{MPa}$.

Four unstrengthened panels were tested under shear-compression as reference. An identical axial load of $400 \mathrm{kN}$ was applied to all specimens to simulate the service gravity loads that typically act on traditional three-story buildings.

\subsubsection{Failure mode and shear strength}

The panels showed a shear-controlled failure mode (diagonal tension), characterized by diagonal cracks that propagated through both mortar joints and stones. The inplane shear strength $\mathrm{V}_{\max }$ was, on average, equal to $132.0 \mathrm{kN}$ (c.o.v. $=26 \%$ ). The walls exhibited relatively large deformations with no relevant strength decay before failure. The ultimate shear strength $\mathrm{V}_{\mathrm{u}}$, calculated as the load corresponding to a strength degradation of $20 \%$ in the softening branch, approached the average value of $120.9 \mathrm{kN}$.

The experimental shear strength is compared with the value predicted by the Turnšek and Căcǒvič's model [24], presented in the Italian code NTC08 as follows:

$$
V_{t}=B \cdot t \cdot \frac{1.5 \tau_{o d}}{b} \sqrt{1+\frac{\sigma_{o d}}{1.5 \tau_{o d}}} \quad b=\frac{H}{B} ; 1 \leq b \leq 1.5
$$

where $B$ is the base and the thickness of the panel; $\sigma_{0}=N / A$ is the axial compressive stress due to $\mathrm{N}=400 \mathrm{kN}$, and A the wall section; od the masonry shear strength obtained through diagonal compression tests. It is worth noting that Eq. 1 is in accordance with the equation provided by FEMA 356 [25] for diagonal tension failure mechanism.

In absence of direct shear tests, the diagonal shear strength can be estimated by using the values provided by the Guidelines to NTC 08 ([26], Table C8A.2.1).

The lower bound strength $\tau_{\text {od }}$ was selected from Table C8A.2.1 as it was close to the experimental compressive strength of $1.1 \mathrm{MPa}$. Therefore, $\tau_{\text {od }}=0.028 \mathrm{MPa}$. Then, that value was corrected through the factors 0.9 and 1.5 that account for the presence of wide core and good transversal connections, respectively ([26], Table C8A.2.2). 
The estimated strength capacity calculated with Eq. (1) resulted $\mathrm{V}_{\mathrm{t}, 1}=132 \mathrm{kN}$, in agreement with the experimental lateral load capacity $\mathrm{V}_{\max }$. The flexural strength calculated in accordance with NTC 08 was $171 \mathrm{kN}$.

\section{Strengthened panels}

\subsection{Test programme}

The experimental tests carried out by Marcari et al [3] included different FRP materials (i.e CFRP vs. GFRP) and different FRP density (i.e. low vs. high).

The plies $200 \mathrm{~mm}$ wide were applied along the wall diagonals, and were anchored through a U-wrap system, characterized by horizontal FRP strips bent along the thickness of the wall, as shown in Figure 1a. As for the FRP density, strengthening with low density (LD) was characterized by one ply, high density (HD) had a number of plies doubled.

The test programme was as follows:

- two panels with LD CFRP: C1a and C1b

- two panels with HD CFRP: C2a and C2b

- one panels with LD GFRP: G1a

- two panels with HD GFRP: G2a and G2b

The mechanical properties of the FRP materials were provided by the manufacturer. For the CFRP: $\mathrm{E}_{\mathrm{f}}=230 \mathrm{GPa}$, ultimate deformation $\varepsilon_{\mathrm{f}, \mathrm{u}}=1.5 \%$, ultimate tensile strength $\mathrm{f}_{\text {frp }}=3450 \mathrm{MPa}$; thickness of a single ply $\mathrm{t}_{\mathrm{f}}=0.167 \mathrm{~mm}$;

For the GFRP: $\mathrm{E}_{\mathrm{f}}=66 \mathrm{GPa}, \varepsilon_{\mathrm{f}, \mathrm{u}}=2.0 \%, \mathrm{f}_{\mathrm{u}}=1320 \mathrm{MPa}$ and thickness $\mathrm{t}_{\mathrm{f}}=0.11 \mathrm{~mm}$. The deformation of the diagonal plies was monitored by using four strain-gauges adhered to the surface of the FRP, as illustrated in Figure $1 \mathrm{~b}$ for the ply in tension.

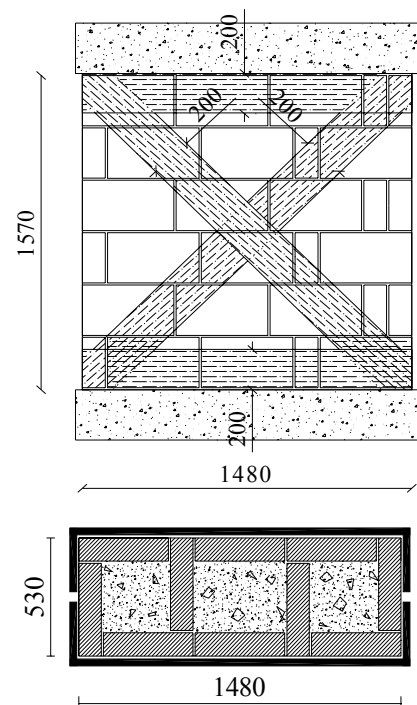

(a)

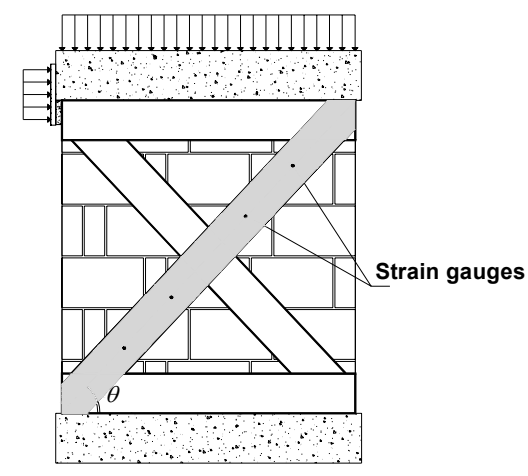

(b)

Figure 1. (a) FRP scheme and U-anchorage system; (b) strain gauges distribution along the diagonal ply. 


\subsection{Failure modes}

The typical crack pattern of the strengthened panels after testing is shown in Figure 2. Cracks started to appear in the bricks along the diagonal of the panel, and propagated through the blocks and mortar joints.

As cracking of masonry spreaded, a truss mechanisms developed with the FRP tensile force reacted by a vertical compression in the masonry. Typically, shear failure was displayed by the panels strengthened with low FRP density (Figure 2). In the case of panels strengthened with high FRP density, like C1b and G1b, large vertical stresses where achieved at the compressive edge, therefore toe crushing and spalling of masonry occurred, as can be seen in Figure 2. The observed failure of panels with high FRP density was thus characterized by a combination of shear and flexure.

The panels G1a and G2b (low density) showed also the failure of the tensile plies, that occurred when the panels reached displacements close to the ultimate.

It should be remarked that the presence of the horizontal anchorage system inhibited the edge-debonding of the plies. The compressed plies exhibited buckling as the magnitude of the applied displacement increased. However, they did not appear to contribute to the overall behaviour of the walls.

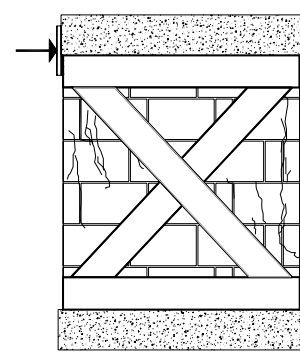

(a)

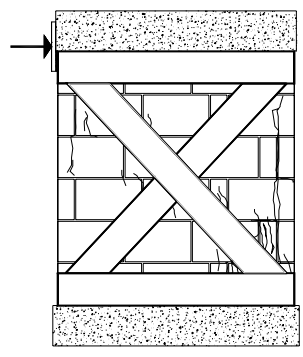

(b)

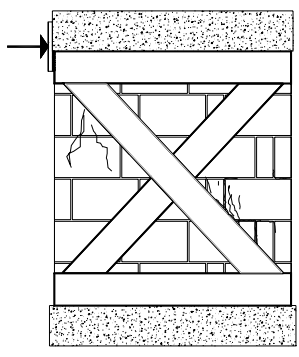

(c)

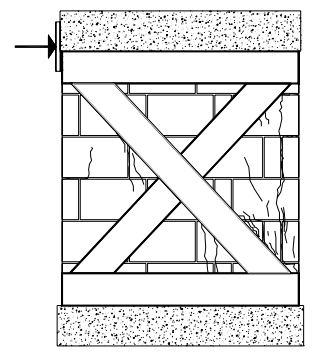

(d)

Figure 2. Typical crack pattern at failure (a) CFRP low density; (b) GFRP low density, (c) CFRP high density and (d) GFRP high density.

\subsection{Shear strength}

The experimental results indicate that all the strengthened specimens exhibited an significant increase in lateral strength. The lateral load versus top horizontal displacement relationships are illustrated in Figure 3 and Figure 4. The average response of the four unstrengthend panels is also plotted as reference. The experimental shear strength values, $\mathrm{V}_{\text {max.str., }}$ of CFRP and GFRP cross layout, as well as the increase in shear capacity $\Delta \mathrm{V}_{\max \text {,str. }}$ are reported in Table 1 .

From comparative analysis it can be pointed out that panels with high density CFRP (i.e. C2a and $\mathrm{C} 2 \mathrm{~b}$ ), showed the highest absolute increase in lateral load resistance 
equals to $75 \%$, whereas low density GFRP (G1a) showed the lowest increase of about $20 \%$.

It was also observed that: (i) the average strength for high density CFRP panels (panels C2) is almost twice that of low density CFRP panels (panels C1); (ii) no significant differences in shear strength were found between low and high GFRP; (iii) the increase was nearly the same for low density CFRP (panels C1) and high density GFRP (panels G2).

\begin{tabular}{|c|c|c|c|c|c|c|}
\hline \multirow{3}{*}{$\begin{array}{l}\text { Panel } \\
\text { label }\end{array}$} & \multirow{3}{*}{$\begin{array}{l}\text { FRP } \\
\text { type }\end{array}$} & \multirow{3}{*}{$\begin{array}{c}\text { FRP } \\
\text { density }\end{array}$} & \multicolumn{2}{|c|}{$\mathrm{V}_{\max , \text { str. }}$} & \multicolumn{2}{|c|}{$\Delta \mathrm{V}_{\max , \mathrm{str}}{ }^{(* *)} \cdot \Delta \mathrm{V}_{\max , \mathrm{str} .} / \mathrm{V}_{\max }{ }^{(*)}$} \\
\hline & & & $\begin{array}{l}\text { Single } \\
\text { values }\end{array}$ & Average & $\begin{array}{l}\Delta V_{\max , s t r} \\
\text { (increase) }\end{array}$ & $\begin{array}{l}\text { (increase) } \\
\text { (inax,str } / V_{\max }\end{array}$ \\
\hline & & & {$[\mathrm{kN}]$} & {$[\mathrm{kN}]$} & {$[\mathrm{kN}]$} & $(\%)$ \\
\hline $\mathrm{C} 1 \mathrm{a}$ & \multirow{4}{*}{ CFRP } & \multirow{2}{*}{ Low } & 156,7 & \multirow{2}{*}{172,8} & \multirow{2}{*}{40,8} & \multirow{2}{*}{31} \\
\hline $\mathrm{C} 1 \mathrm{~b}$ & & & 188,9 & & & \\
\hline $\mathrm{C} 2 \mathrm{a}$ & & \multirow{2}{*}{ High } & 180,6 & \multirow{2}{*}{203,8} & \multirow{2}{*}{98,8} & \multirow{2}{*}{75} \\
\hline $\mathrm{C} 2 \mathrm{~b}$ & & & 227,0 & & & \\
\hline G1a & \multirow{3}{*}{ GFRP } & Low & & & 23,8 & 18 \\
\hline G2a & & \multirow{2}{*}{ High } & 179,5 & \multirow{2}{*}{165,4} & \multirow{2}{*}{33,4} & \multirow{2}{*}{25} \\
\hline $\mathrm{G} 2 \mathrm{~b}$ & & & 147,4 & & & \\
\hline
\end{tabular}

(*) $\mathrm{V}_{\max }=$ Average peak load of the unstrengthened panels equals to $132 \mathrm{kN}$ (**) $\Delta \mathrm{V}_{\text {max,str. }}=\mathrm{V}_{\text {max,str. }}-\mathrm{V}_{\max }$

Table 1. Experimental results

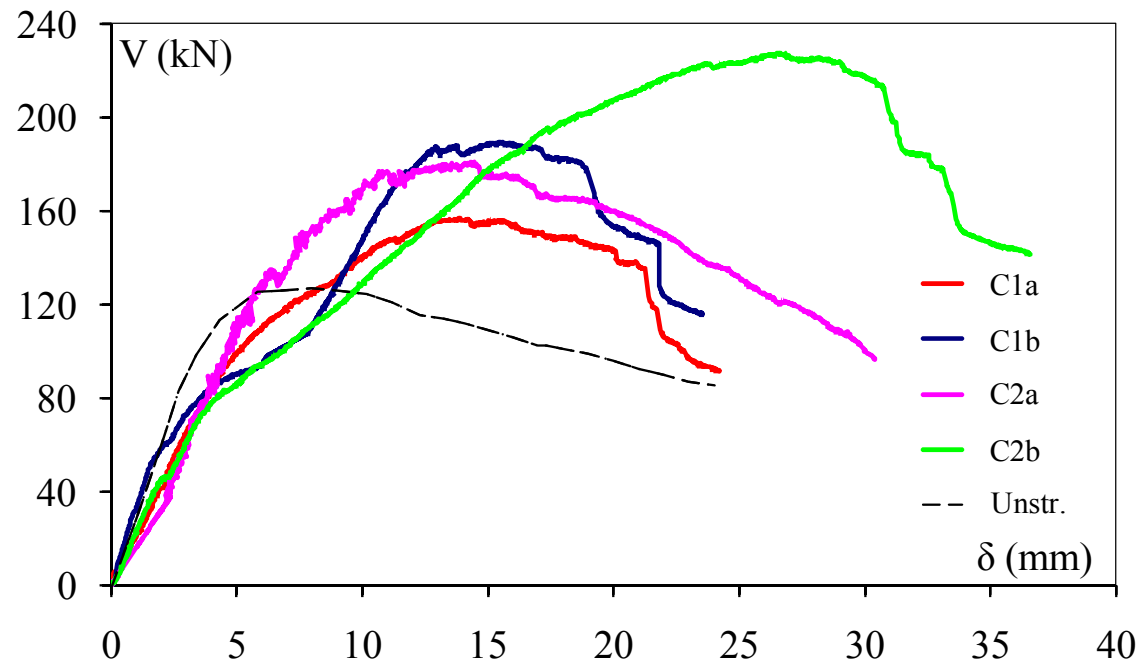

Figure 3. Force-displacement curves of CFRP strengthened panels 


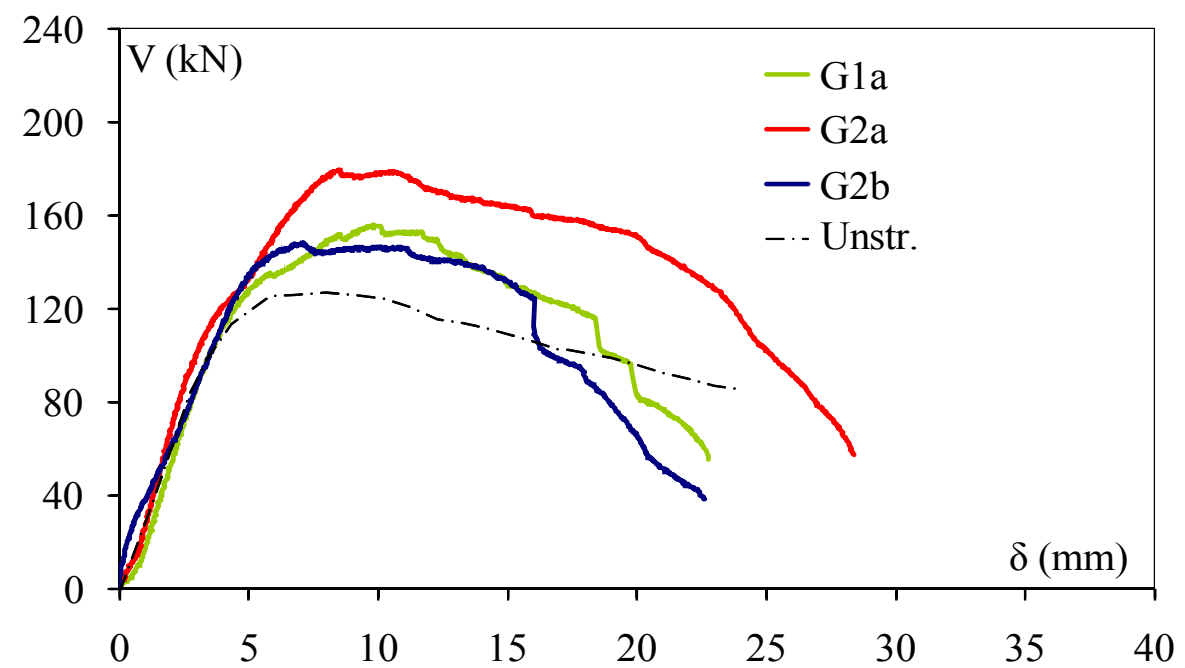

Figure 4. Force-displacement curves of GFRP strengthened panels

\subsection{FRP strains}

The strain gauges allowed for interrogation of the debonding phenomenon between FRP and the masonry support. The strains measured along the tensile plies have been plotted against the top horizontal displacement of panel $\mathrm{Cla}$ are illustrated in Figure 5. Moreover, in Figure 5 the strain profiles of panel $\mathrm{C} 1 \mathrm{a}$ are compared against the shear strength - horizontal displacement curve.

By crossing strain data with the information gathered from visual observation of debonding process, it was possible to estimate the intermediate debonding strain of the plies in tension. Experimental data have been obtained for both CFRP and GFRP and are summarised in Table 2.

\begin{tabular}{|c|c|c|c|c|}
\hline \multirow{2}{*}{$\begin{array}{l}\text { Panel } \\
\text { label }\end{array}$} & \multirow{2}{*}{$\begin{array}{l}\text { FRP } \\
\text { type }\end{array}$} & \multirow{2}{*}{$\begin{array}{c}\text { FRP } \\
\text { density }\end{array}$} & \multicolumn{2}{|c|}{ Strains } \\
\hline & & & Single value & Average \\
\hline Cla & \multirow{4}{*}{ CFRP } & \multirow{2}{*}{ Low } & 0,002772 & \multirow{2}{*}{0,002881} \\
\hline $\mathrm{Clb}$ & & & 0,00299 & \\
\hline $\mathrm{C} 2 \mathrm{a}$ & & \multirow{2}{*}{ High } & 0,002485 & \multirow{2}{*}{0,002274} \\
\hline $\mathrm{C} 2 \mathrm{~b}$ & & & 0,002062 & \\
\hline G1a & \multirow{3}{*}{ GFRP } & Low & 0,00332 & 0,00332 \\
\hline G2b & & \multirow{2}{*}{ High } & 0,003621 & \multirow{2}{*}{0,003093} \\
\hline G2a & & & 0,002564 & \\
\hline
\end{tabular}

Table 2. Experimental intermediate debonding strains 


\subsection{FRP contribution to panel shear strength}

According to technical literature, it is here assumed that the shear contribution of FRP is evaluated as the horizontal component of the tensile force in the diagonal plies. Once known the FRP strains as a function of the horizontal displacement $\varepsilon_{\text {frp }}(\delta)$ - (Figure 5), the experimental shear contribution due to FRP can be estimated as follows:

$$
V_{R, f r p}=\varepsilon_{f r p} \times E_{f} \times A_{f r p} \times \cos \theta
$$

where $A_{\text {frp }}$ is the area of the FRP plies on both sides of the panel; $\theta$ the angle between the diagonal ply and the horizontal direction. In Figure 6 the experimental shear load $\mathrm{V}_{\mathrm{R} \text {,frp }}$ is plotted against the horizontal displacement for panels $\mathrm{G} 1 \mathrm{a}$ and G2a. It can be seen that the load carried by the FRP increased with displacement, but that increase was not fully linear.

The in-plane behaviour of the strengthened panels under horizontal displacement is here discussed referring to Figure 5 and Figure 6.

At small displacements, the FRP was fully bonded to the uncracked masonry and acted compositely with the masonry. The strengthened stiffness was not significantly greater than for the unreinforced masonry, so that the FRP did not initially increase the load carried by the specimen. As the displacement increased, the FRP started to debond due to cracks in the masonry, accompanied by an approximately linear increase in strain and corresponding stress.

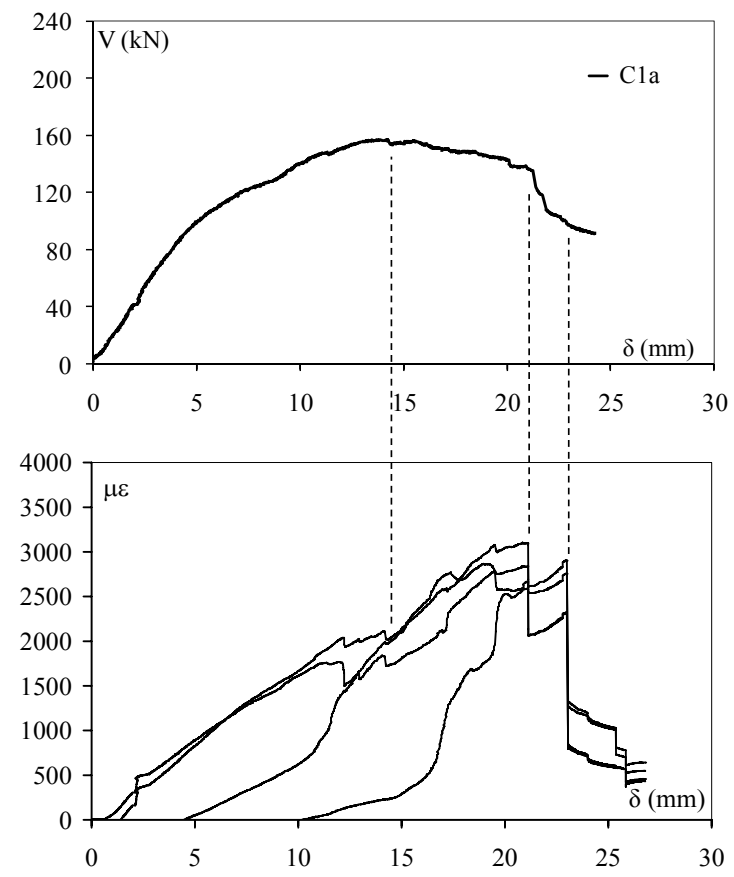

Figure 5. Panel C1a: Comparison of the force - displacement curve against the FRP strain profile 


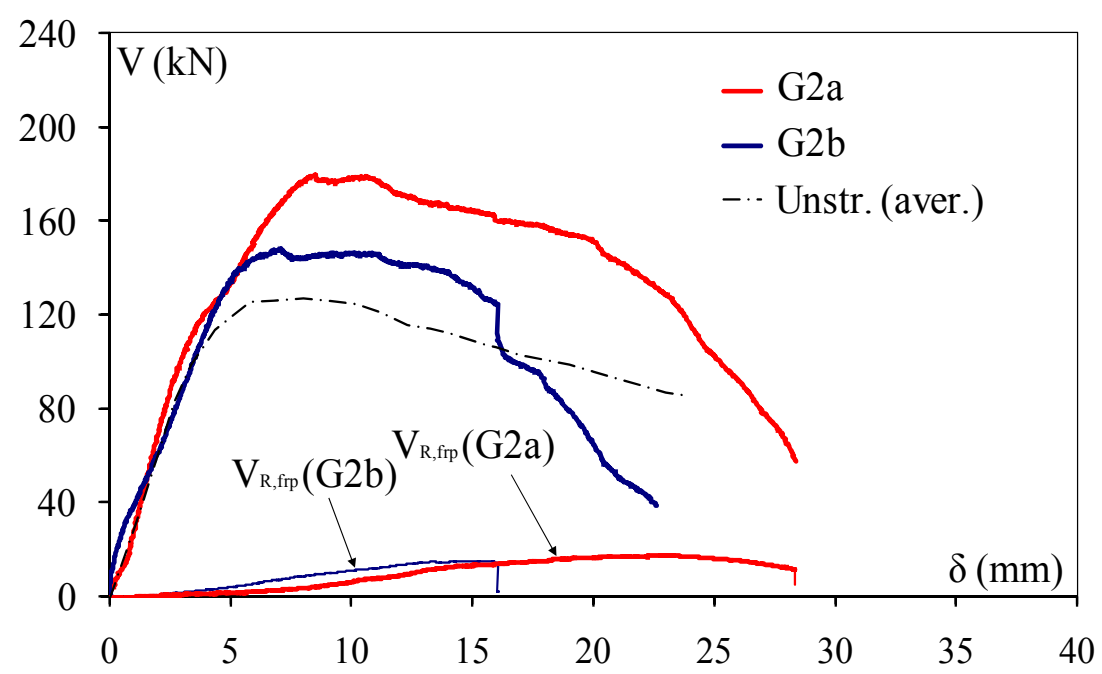

Figure 6. FRP contribution to panel shear strength

At this stage, the FRP restrained the growth of cracks in the masonry, and thus the load carried by the strengthened specimen started to increase with displacement. The panels carried shear by a truss mechanism, with the diagonal tensile action through the FRP that was reacted by a vertical compression in the masonry. The increased vertical load can be estimated as follows:

$$
N_{m, f r p}=V_{R, f r p} \times \tan \theta
$$

It can be observed from Figure 6 that the maximum shear force $V_{R \text {,frp }}$ and the peak load $\mathrm{V}_{\max }$ of panel $\mathrm{Cla}$ were attained under different displacements. The drop in the load capacity detected at around $20 \mathrm{~mm}$ was due to loss of debonding of the entire ply, as can be seen from the drop in the strain profile in Figure 5. However, the ply was able to carry further tension due to the presence of the end-anchorage. A similar behaviour was detected in all the strengthened specimens. The maximum values of $V_{R, \text { frp }}$ and $\mathrm{N}_{\mathrm{m} \text {,frp }}$ have been summarised in Table 3 .

\subsection{Masonry contribution to panel shear strength}

The contribution to shear due to masonry $\left(V_{\max }\right)$ and FRP $\left(V_{R, f r p}\right)$ cannot be in principle simply superposed because they occurred at different horizontal displacement, as can be see Figure 6. However, the summation of the maximum values of both the contributions is a common approach of the scientific community, as it can provide an estimate of the upper bound of the lateral strength of the reinforced panels ([10]).

Therefore, from the experimental values $V_{\max }$ and $V_{R \text {,frp }}$ defined above, the experimental shear carried through the masonry $\left(\mathrm{V}_{\mathrm{R}, \mathrm{m}}{ }^{\prime}\right)$ can be calculated with Eq. 3, and results are reported in Table 3: 


$$
V_{R, m}^{\prime}=V_{\text {max }, s t r .}-V_{R, f r p}
$$

It can be observed that $\mathrm{V}_{\mathrm{R}, \mathrm{m}}$ values are greater than the shear capacity of the bare specimen $\mathrm{V}_{\max }=132 \mathrm{kN}$. This is due to the increased vertical load due to FRP that confines the masonry and allows it to carry increased shear load.

Experimental data on the strengthened panels allowed to assess reliability of Turnšek's model proposed by NTC 08 in predicting the shear load carried out through masonry.

The vertical load through the masonry was increased by truss action due to FRP reinforcement, and the resulting compressive load at the was equal to $\mathrm{N}_{\mathrm{o}}+\mathrm{N}_{\mathrm{m} \text {,frp }}$, with $\mathrm{N}_{\mathrm{o}}=400 \mathrm{kN}$ the vertical prestress. The masonry shear strength $\mathrm{V}^{\prime} \mathrm{m}$ corresponding to the increased vertical load has been calculated in accordance with Eq. 1, and the results are illustrated in Table 3.

Analysis of results show that the ratio $\mathrm{V}_{\mathrm{m}}^{\prime} / \mathrm{V}_{\mathrm{m}}$ is close to unit, thus Turnšek's model provides results in good agreement with the experimental masonry shear strength, both for CFRP and GFRP strengthened panels.

\begin{tabular}{|c|c|c|c|c|c|c|c|}
\hline \multirow{3}{*}{ Panel label } & \multirow{2}{*}{$\mathrm{V}_{\max }$} & \multirow{2}{*}{$\mathrm{V}_{\mathrm{R}, \mathrm{frp}}$} & \multicolumn{2}{|c|}{$\begin{array}{c}\mathrm{V}_{\mathrm{m}} \\
\text { (Eq. ) }\end{array}$} & \multirow{2}{*}{$\begin{array}{l}\mathrm{N}_{\mathrm{m}, \mathrm{frp}} \\
(\mathrm{Eq} .)()\end{array}$} & \multirow{2}{*}{$\mathrm{V}_{\mathrm{m}}^{\prime}($ Eq. 1) } & \multirow{2}{*}{\begin{tabular}{|l}
$\mathrm{V}^{\prime}{ }_{\mathrm{m}} / \mathrm{V}_{\mathrm{m}}$ \\
Average
\end{tabular}} \\
\hline & & & $\begin{array}{l}\text { Single } \\
\text { value }\end{array}$ & Average & & & \\
\hline & $\mathrm{kN}$ & $\mathrm{kN}$ & $\mathrm{kN}$ & $\mathrm{kN}$ & $\mathrm{kN}$ & $\mathrm{kN}$ & - \\
\hline C1a & 156,7 & 28,0 & 128,7 & \multirow{2}{*}{143,3} & 30,7 & 137 & \multirow{2}{*}{0,97} \\
\hline $\mathrm{C} 1 \mathrm{~b}$ & 188,9 & 31,0 & 157,9 & & 33,8 & 138 & \\
\hline $\mathrm{C} 2 \mathrm{a}$ & 180,6 & 58,0 & 122,6 & \multirow{2}{*}{153,3} & 61,0 & 141 & \multirow{2}{*}{0,95} \\
\hline $\mathrm{C} 2 \mathrm{~b}$ & 227,0 & 43,0 & 184,0 & & 46,0 & 139 & \\
\hline G1a & 155,8 & 8,7 & 147,1 & 147,1 & 9,2 & 134 & 0,83 \\
\hline G2a & 179,5 & 17,2 & 162,3 & \multirow{2}{*}{147,4} & 18,2 & 135 & \multirow{2}{*}{0,93} \\
\hline $\mathrm{G} 2 b$ & 147,4 & 14,9 & 132,5 & & 15,8 & 135 & \\
\hline
\end{tabular}

Table 3. Shear strength contributions due to masonry and FRP

\subsection{Shear strength associated to the compressive failure of the masonry diagonal strut}

The shear strength of FRP-strengthened masonry panels can be obtained in accordance with CNR DT as the smaller value of:

$$
V_{R d}=\min \left(V_{R d, m}+V_{R d, f} ; V_{t c}\right)
$$

where $V_{R d, m}$ and $V_{R d, f}$ are the design shear strength of masonry and FRP, respectively, and $\mathrm{V}_{\mathrm{t}, \mathrm{c}}$ the design lateral strength corresponding to compressive failure of the masonry diagonal strut. The strength $V_{\text {tc }}$ is given by Eq. 5: 


$$
V_{t c}=0.3 \cdot t \cdot d \cdot f_{w h, c}
$$

where $t=$ panel thickness, $f_{w h, c}=$ horizontal compressive masonry strength and $d=$ distance between the compression side of the masonry and the centroid of FRP flexural strengthening. Since no indications have been provided by the CNR DT about cross layouts, it is here assumed $\mathrm{d}=0.8 \mathrm{~B}$, with $\mathrm{B}=$ base of the panel. The compressive strength is $f_{\mathrm{wh}, \mathrm{c}}=50 \%$ of the vertical compressive strength as suggested by CNR DT (i.e. $f_{w h, c}=0.55 \mathrm{MPa}$ ). It can be recognised that Eq. 5 provides a very conservative value of the lateral strength, i.e. $\mathrm{V}_{\mathrm{t}, \mathrm{c}}=101 \mathrm{kN}$, thus the panel failure mode would be dominated by crushing of the diagonal strut, in contrast with the experimental evidence. Further investigation on Eq. 4 is clearly needed.

\section{Conclusions}

On the basis of experimental data available in literature, the work presented a quantitative evaluation of FRP contribution to the shear strength of FRP-tuff masonry reinforced with cross configuration. The strain measurement allowed to investigate the role played by the plies during the test. In particular, the FRP contribution has been analysed and discussed for both CFRP and GFRP panels, either in low or high FRP density. As for the masonry contribution, it was found good agreement between the experimental strength data and the values predicted through the Turnšek 's model . Furthermore, comparative analysis have shown that the equation provided by the CNR DT 200/2004 for the calculation of the shear strength associated to the compressive failure of the masonry diagonal strut, can led to results not confirmed by the experimental evidence.

It is expected that further research supported by refined numerical analysis may provide additional data and insight into the behaviour of FRP-reinforced tuff masonry.

\section{References}

[1] A. Calderoni, G. Cecere, E.A. Cordasco, L. Guerriero, P. Lenza, G. Manfredi, "Metrological definition and evaluation of some mechanical properties of post-medieval Neapolitan yellow tuff masonry", Journal of Cultural Heritage $11,163-171,2010$.

[2] G. Marcari, G. Fabbrocino, P. Lourenço, "Investigation into compressive behaviour of tuff masonry panels", Proc. Wondermasorny 2, Workshop on design for rehabilitation of Masonry Structures, Lacco Ameno, Ischia, Italy, 2009.

[3] G. Marcari, G. Manfredi, A. Prota, M. Pecce, "In-plane shear performance of masonry panels strengthened with FRP”, Composite Part B 38, 887-901, 2007.

[4] C. Faella, E. Martinelli, E. Nigro, S. Paciello, "Shear capacity of masonry walls externally strengthened by a cement-based composite material: An experimental campaign”, Construction and Building Materials 24, 84-93, 2010. 
[5] A. Prota, G. Marcari, G. Fabbrocino, G. Manfredi, C. Aldea, "Experimental in-plane behavior of tuff masonry strengthened with cementitious matrix-grid composites", Journal of Composites for Construction, Vol. 10(3), pp. 223-233, 2006.

[6] G. Bergamo, M. Eusebio, G. Manfredi, Prota, A., "Shake Table Test on a Tuff Masonry Building," 8th US National Conference on Earthquake Engineering, Paper 698, Earthquake Engineering Research Institute, San Francisco, CA, (CD-ROM), 2006.

[7] I. Langone, A. Prota, G. Bergamo, G. Manfredi, "Analisi sperimentale su tavola vibrante di due modelli in muratura di tufo consolidati mediante materiali compositi", Proc. XIII Convegno ANIDIS "L' ingegneria Sismica in Italia", (CD-ROM), 2009.

[8] E. Cosenza, G. Manfredi, A. Occhiuzzi, M., Pecce, "Toward the investigation of the interface behaviour between tuff masonry and FRP fabrics", Proc. International Conference on Mechanics of Masonry Structures Strengthened with FRP Materials: Modeling, Testing design, Control. Venezia (Italy), 2000.

[9] NTC 08 - Norme tecniche per le costruzioni, D.M. 14 gennaio 2008 (G.U. n. 29 del 04.02.2008, Suppl. Ord. n.30).

[10] European Committee for Standardization (CEN 2001). "Design of masonry structures. Part 1-1: General rules for Building-Rules for reinforced and unreinforced masonry." Eurocode 6, CEN, Brussels, Belgium.

[11] American Concrete Institute (ACI). Guide for the Design and Construction of Externally Bonded FRP systems for strengthening URM structures. Draft version of ACI 440 Committee, July, 2008.

[12] CNR-DT 200/2004, Guide for the Design and Construction of Externally Bonded FRP Systems for Strengthening Existing Structures, CNR - National Research Council, Rome, Italy, 2008, http://www.cnr.it.

[13] Y. Zhunge, "FRP retrofitted URM walls under in-plane shear - review and assessment of available models", Journal of Composites for Construction, 2010.

[14] G. Manfredi, L. Ascione, "Innovative materials for the vulnerability mitigation of existing structures", The state of Earthquake Engineering Research in Italy: the ReLUIS-DPC 2005-2008 Project, G. Manfredi and M. Dolce (Eds), 2008.

[15] P. Roca, and G. Araiza, "Shear response of brick masonry small assemblages strengthened with bonded FRP laminates for in-plane reinforcement", Construction and Building Materials, 24, 1372-1384, 2010.

[16] A. Benedetti, E. Steli, "Analytical models for shear-displacement curves of unreinforced and FRP reinforced masonry panels", Construction and Building Materials 22, 175-185, 2008.

[17] T. Triantafillou, "Strengthening of masonry structures using epoxy-bonded FRP laminates", Journal of Composites for construction, 2(2), 95-104, 1998.

[18] A. Prota, G. Manfredi, F. Nardone, "Assessment of Design Formulas for InPlane FRP Strengthening of Masonry Walls", Journal of Composites for Construction, 12(6), 643-649, 2008. 
[19] T. Zhao, C.J. Zhang, J. Xie, "Experimental Study on Earthquake Strengthening of Brick Walls with Continuos Carbon Fibre Sheet", Masonry International, 16 (1), 21-25, 2003.

[20] T. Zhao, C.J. Zhang, J. Xie, "Shear Behaviour of UCMW using CFRP Sheet: A Case Study", The Masonry Society Journal, 22 (1), 87-95, 2004.

[21] C. Faella, E. Martinelli, E. Nigro, S. Paciello, "Shear capacity of masonry walls externally strengthened by a cement-based composite material: An experimental campaign", Construction and Building Materials, 24, 84-93, 2010.

[22] T. Stratford, G. Pascale, O. Manfroni, B. Bonfiglioli, "Shear strengthening masonry panels with sheet glass-fiber reinforced polymer", Journal of Composites for Construction, 8(5), 434-443, 2004.

[23] G. Marcari, G. Fabbrocino, P. Lourenço, "Mechanical properties of tuff and calcarenite masonry panels under compression", Proc. 8IMC Conference, Dresden (CD-rom), 2010

[24] V. Turnšek, F. Căcŏvič, "Some experimental results on the strength of brick masonry walls", Proc. 2nd International Brick Masonry Conference, Stoke-onTrent, 149-156, 1971.

[25] FEMA 356 "Prestandard and Commentary for the Seismic Rehabilitation of Buildings", ASCE for the Federal Emergency Management Agency, Washington, D.C., November 2000.

[26] Istruzioni per l'applicazione delle "Nuove norme tecniche per le costruzioni", di cui al decreto ministeriale 14 gennaio 2008. Circolare del 2/2/2009, n. 617 del Ministero delle Infrastrutture e dei Trasporti approvata dal Consiglio Superiore dei Lavori Pubblici, Suppl. ord. n. 27 alla G.U. del 26/02/2009 n. 47. 